\title{
Sykepleiere trenger kollegastøtte når \\ uønskede hendelser \\ skjer (2:3)
}

Som sykepleiere har vi kunnskapen vi trenger for å ta vare på våre kollegaer i vanskelige situasjoner. Godt ivaretatte sykepleiere har mindre fravær.

\section{Elin Sagbakken}

Sykepleier og medlem av Rådet for sykepleieetikk

Kirkenes sykehus, Finnmarkssykehuset

Etikk Kollegastøtte Uheldige hendelser

\section{Hovedbudskap}

I et stadig mer krevende helsevesen er det viktigere enn noen gang å ta vare på kollegaer når noe går galt. Vi må bidra til å rydde i begreper som ansvar, skyld og skam. Å bli stående alene igjen med disse tankene kan føre til uhelse. Ved å snakke om og ta lærdom av det som skjedde, kan vi bidra til at arbeidsmiljøet blir både etisk håndterlig og bærekraftig. Vi har et kollektivt ansvar for dette, både som kollegaer og ledere. Artikkelen er den andre av tre artikler som handler om kollegast $\varnothing t t e$. 
Vi må ikke undervurdere hvor sterkt involvert mange av oss er i ulike pasient- og pårørenderelasjoner. Vi har kanskje fulgt den samme pasienten, de samme pårørende eller den samme familien over lang tid.

Mange av oss har en sterk autonomi i utøvelsen av faget vårt. Når da en kritisk hendelse oppstår, og i verste fall med døden som resultat, vil det påvirke vår psykiske helse - uavhengig av om hendelsen er menneskepåført eller ikke.

Hvor dramatisk eller stressende den enkelte helsearbeideren opplever situasjonen, er individuelt. Kroppen og hjernen sørger vanligvis selv for å reparere traumatiske enkelthendelser. God kollegial støtte eller samtale med psykolog kan være viktig for å komme seg gjennom denne prosessen.

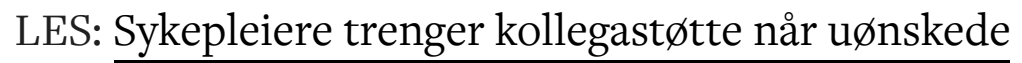
hendelser skjer (1:3)

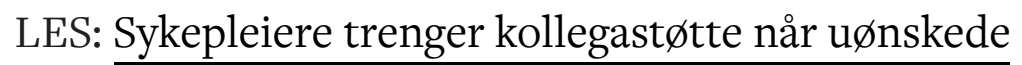
hendelser skjer (3:3)

\section{Tåler noen mer enn andre?}

I mange år har helsepersonell stilt spørsmål om hvorvidt noen mennesker er sterkere rustet enn andre til å tåle påkjenninger fra naturens side. Hvordan man kommer seg gjennom ulike hendelser, beror nok først og fremst på faktorer man ikke har kontroll over.

Sosial st $\varnothing t t e$ i etterkant er viktig. «Vi blir først og fremst sterke gjennom hverandre», sier psykologspesialist Dag Nordanger til tidsskriftet Psykologisk. Det å ha et trygt og godt liv er også viktig, mener Nordanger (1).

Konsekvensene kan bli store hvis den enkelte helsearbeideren ikke blir fanget opp og får den nødvendige støtten og hjelpen. 
I mediene er det av og til noen som står frem og mener at de som har gjort feil, slipper altfor lett unna. Hva vet vi egentlig om det? Det fremkommer sjelden eller aldri hvordan den enkelte helsearbeideren har det $\mathrm{i}$ etterkant av den uheldige hendelsen. Den eller de involverte straffes allerede hardt gjennom skyldfølelse, selvbebreidelse og personlige kriser.

Mange føler at de står alene, og kjenner på skyldfølelse og skam i tillegg til sorgen over skaden de påførte pasienten eller dødsfallet de forårsaket. Som sykepleier er det også sterkt å kjenne på medfølelsen med de pårørende som står igjen. Hvis saken er av en slik karakter at helsearbeideren blir avhørt av politiet og gransket av Helsetilsynet, vil det også være en stor tilleggsbelastning (2).

\section{Å være sykepleier innebærer å ha ansvar}

Få sykepleiere og leger går gjennom yrkeslivet uten å ha kjent på ansvar, skyld eller skam for en uønsket hendelse. Noen ganger begår vi tydelige feil. Andre ganger pålegger vi oss selv skyld og skam, der begrepene ansvar og skyld ofte blandes (3).

Begrepet «ansvar» definerer meg som sykepleier. $\AA$ være ansvarlig innebærer at jeg er aktiv, selvbevisst og skapende overfor omgivelsene, og jeg inntar en rolle som ansvarlig sykepleier.

\section{«Begrepet 'ansvar' definerer meg som sykepleier.»}

Om jeg definerer meg uten ansvar, inntar jeg derimot en passiv rolle til omgivelsene. Ansvarsbegrepet sier altså noe om hva og hvem vi er, hvordan vi evner å reflektere over og tar ansvar for våre gode og dårlige valg. Begrepet har mange nyanser, og forskjellige sykepleiere har ulike typer ansvar for pasientene.

Det er alltid flere berørte parter i en sak eller uønsket hendelse. Når vi i Rådet for sykepleieetikk og i kliniske etikkomiteer skal vurdere innkomne saker, benytter vi oss av en strukturert modell: SME-modellen (se faktaboks), som er en sjekkliste for etisk refleksjon (4). 
Et av punktene i denne modellen er «berørte parter». I denne konteksten kan vi tenke at når en uønsket hendelse oppstår, vil de berørte partene være pasienten, de pårørende og helsearbeiderne som er involvert.

\section{SME-modellen}

SME står for Senter for medisinsk etikk. SME-modellen brukes til å drøfte etiske dilemmaer i helsetjenesten. Modellen omfatter seks punkter:

1. Hva er det etiske problemet?

2. Hva er fakta i saken?

3. Hvem er berørte parter, og hva er deres syn og interesser?

4. Hvilke verdier, prinsipper og lover er relevante?

5. Hvilke handlingsalternativer finnes?

6. Drøfting, konklusjon med begrunnelse for akseptable handlingsalternativer.

Kilder: $\underline{\text { KS }}$ og Senter for medisinsk etikk

I del 1 i yrkesetiske retningslinjer står følgende:

«Sykepleieren og profesjonen. Sykepleieren har et

faglig, etisk og personlig ansvar for egne handlinger og vurderinger i utøvelsen av sykepleie, og setter seg inn i det lovverk som regulerer tjenesten» (5).

Når vi utvider ansvaret mot hvem som står ansvarlig for hendelsen, kommer flere parter inn i bildet: nærmeste leder, som er ansvarlig for opplæringen du fikk som nyansatt, eller eventuelt ikke fikk. Over der igjen, ledere som sørger for at folk med tilstrekkelig kompetanse og riktig antall personer er på jobb. I tillegg vil politikere med flere være ansvarlige når vi utvider ansvaret (6).

\section{Vi må skille mellom ansvar og skyld}


Som helsearbeider trenger vi hjelp fra lederen og kollegiet til å sortere begreper som ansvar, skyld, skyldfølelse og skam. Ingen av disse begrepene er enkle, og vi kan fort rote det til for oss selv, med uønskede konsekvenser som resultat.

Ifølge Mesel (3) klarer helsepersonell ofte ikke å skille mellom ansvar og skyld. Han mener at disse to begrepene er helt forskjellige.

Først og fremst er vi ansvarlig for å utøve sykepleie gjennom selve profesjonen vår (7). En sykepleierkollega uttrykte det så fint en gang: «Når vi har aktivert ID-kortet vårt på starten av en vakt, innebærer det at vi må legge vekk privatpersonen i oss og ta på oss hatten som den profesjonelle sykepleieren.» Det innebærer blant annet å forholde seg til lovverket og de yrkesetiske retningslinjene. Vi inntar en ansvarlig rolle.

\section{«Det å ha pasientansvar når noe går galt, er ikke ensbetydende med å ha skylden.»}

Selv om jeg har ansvaret for en pasient som d $\varnothing \mathrm{r}$ uventet, betyr det nødvendigvis ikke at jeg kan klandres for dødsfallet. Det å ha pasientansvar når noe går galt, er ikke ensbetydende med å ha skylden. Å ta ansvar er å være villig til å stå frem og informere og forklare pasienten eller de pårørende om hva som er skjedd, og hvorfor jeg handlet som jeg gjorde.

Den som rammes når noe går galt, ønsker at de involverte tar ansvar. Dessverre hender det at den største feilen gjøres etter at den uønskede hendelsen har skjedd, ved at man fors $\varnothing$ ker å dekke over. Pasientens tillit til helsevesenet $\varnothing$ delegges ikke av at vi gjør feil, men av at vi ikke tar ansvar $(2,3)$. 


\section{Manglende støtte kan føre til skyld og skam}

Skyldforholdet er avgrenset og konkret: Det har skjedd noe mellom mennesker, og det handler om et «jeg» og et «du». Skyldfølelse derimot, peker mot selve handlingen, minner meg på det jeg har gjort, eller unnlatt å gjøre. Skam handler om følelser i meg selv, og ikke det jeg har gjort.

Hvis en sykepleier blir møtt med «empatisk taushet» av kollegaene etter en uønsket hendelse, får skamfølelsen gode vekstvilkår hos sykepleieren. Vedkommende får lyst til å gjemme seg bort, trekke seg tilbake og isolere seg (3).

\section{Hvorfor er etikken så viktig?}

«Bærekraft» er vanligvis et begrep vi bruker for å karakterisere $\varnothing$ konomiske, sosiale, institusjonelle og miljømessige sider ved menneskelige samfunn.

Terje Mesel bruker bærekraft i en annen betydning. Han beskriver moralsk bærekraft når sykepleiere kan ut $\varnothing v e$ godt faglig arbeid over tid uten å bli utarmet moralsk sett. I boken Når noe går galt skriver Mesel blant annet om bærekraftig etikk i moralske risikosoner (3). Der hevder han at når arbeidet vi utfører, er av en slik art at det kan påføre skade på pasienter, kollegaer og helsearbeideren selv, befinner vi oss i en risikosone.

Er deler av helsevesenet også en moralsk risikosone? Ja, kan mange av oss tenke. Det profesjonelle arbeidet en sykepleier gjør, utføres i et felt med stor grad av sårbarhet i tillegg til allerede nevnte risiko for skade og uheldige hendelser.

Og det er her i dette landskapet vi utøver vår sykepleie. I denne moralske risikosonen kan sykepleieren bli involvert i hendelser der pasienten blir påført skade. Belastningen kan bli stor for sykepleieren og kollegaene. 
Hvordan skal man sikre seg i denne risikosonen, slik at arbeidsmiljøet blir både etisk håndterlig og moralsk bærekraftig for dem som jobber der?

I de ulike relasjonene vi inngår $i$, handler det om hvem vi er, og hvem vi bør være som profesjonsutøvere. Etikk handler om holdninger og verdier i praksis og om hvorvidt eller hvordan vi uttrykker disse.

Sykepleiefaget og profesjonsetikken favner alt fra organisering og ledelse til menneskemøtet - det være seg møtet med pasienten, de pårørende eller kollegaen. Profesjonsetikken krever noe av meg som sykepleier. Den krever at jeg ser det sårbare i enhver situasjon, at jeg reflekterer, at jeg handler, og ikke minst at jeg evaluerer situasjonene i etterkant.

\section{Nærhetsetikk er også relasjonsetikk}

Nærhetsetikken, møtet og samspillet med det andre mennesket - pasienten, de pårørende og kollegaen - er også relasjonsetikk, som setter forholdet mellom mennesker i sentrum (8).

Sykepleierens holdninger, væremåte og handlingsvalg skal oppleves godt for de involverte i en situasjon. Her blir kommunikasjonen mellom mennesker viktig. Vi mennesker utleverer oss når vi snakker sammen, og vår sårbarhet øker i situasjoner der noe står på spill. Det koster å dele sin smerte, også for sykepleiere.

Nærhetsetikken vektlegger følelsenes betydning for å oppfatte at faglige og etiske verdier står på spill (8). Som sykepleier må jeg være oppmerksom på det «spesielle» i situasjonen og selve møtet med den andre. Jeg må være var for den andre i dennes situasjon for å kunne se hvilke verdier det handler om for kollegaen eller pasienten.

\section{«Det koster å dele sin smerte, også for sykepleiere.»}


Når jeg er kjent med at en kollega har vært medvirkende i en uønsket hendelse, blir mine holdninger og væremåte viktige i møtet og samspillet med kollegaen min. Hvordan kan jeg vise min kollega at jeg ser og forstår? Og hvordan skal jeg lese og tolke den andres kroppsspråk?

Den franske filosofen Emmanuel Lévinas er en av nærhetsetikkens fremste forfattere (8). Han gjør meg oppmerksom på nettopp dette - at den «andre» alltid vil være ny og annerledes for meg - jeg må «svare» den andre der og da.

Ingen menneskem $\varnothing t e r$ er like - det er en etisk grunnforutsetning som ligger i det å være menneske. Lévinas er tydelig på det moralske ansvaret vi har i menneskem øtene, et ansvar vi ikke kan velge bort. Derfor er vi alltid i en mottakerposisjon overfor den andre (8).

\section{Hvordan kan etikken bli bærekraftig?}

Bærekraftig profesjonsetikk innebærer både individuelle og kollektive strategier. At etikken defineres som bærekraftig, vil si at den opprettholdes over tid, at vi som sykepleiere mestrer å stå i ulike situasjoner. Jeg tror, som også Mesel beskriver i sin bok, at vi må bli mer bevisst på å forankre etikken i kollegiet og ikke kun i individet. Slik kan den bli mer bærekraftig.

Vi må definere hendelsen som et kollektivt ansvar, ta eierskap til hendelsen, snakke om det som skjedde sammen med pasienter, pårørende og kollegaer. Få denne kollegiale tenkningen inn i avdelingens kultur: Hva vil det si å være profesjonell hos oss? Jo, vi eier det som skjer sammen - vi håndterer det sammen. Vi må gjøre hverandre bærekraftige (3). 
Våre yrkesetiske retningslinjer (5) er kollektive verdier - der definerer vi det som pasienter, pårørende og kollegaer kan forvente av oss. Følger vi opp disse retningslinjene i kollegiet og organisasjonen vår, er vi langt på vei til å kunne si at vi har en bærekraftig organisasjonskultur.

\section{Vi må være der for hverandre}

Det går galt av og til. Heldigvis blir de fleste feil oppdaget før de får store konsekvenser. Gjennom vår utdanning og profesjon har vi kunnskap til å gi støtte i vanskelige pasient- og pårørendesituasjoner.

La oss ikke glemme den kunnskapen når det gjelder våre egne kollegaer - når de trenger oss som mest. Jeg tror at trygge og godt ivaretatte sykepleiere fører til mindre fravær og til at flere forblir i yrket sitt.

\section{Referanser}

1. Baksaas JM. Hva skal til for å komme over et traume? Psykologisk. 21.07.2021. Tilgjengelig fra: https://psykologisk.no/2021/07/hva-skal-til-for-akomme-over-et-traume/?lp_txn_id=67794 (nedlastet 27.08.2021).

2. Vangsnes L-E. Når det går galt. Tidsskr Nor Legeforen. 2019:(18). Tilgjengelig fra:

https://tidsskriftet.no/2019/12/fra-redaktoren/nar-detgar-galt (nedlastet 27.08.2021).

3. Mesel T. Når noe går galt. Fortelling om skam, skyld og ansvar i helsetjenesten. Oslo: Cappelen Damm Akademisk; 2014.

4. Universitetet i Oslo (UiO). Senter for medisinsk etikk (SME). Oslo: UiO, Institutt for helse og samfunn; 2021. Tilgjengelig fra: https://www.med.uio.no/helsam/om/organisasjon/avdel inger/sme/ (nedlastet 06.09.2021). 
5. Norsk Sykepleierforbund (NSF). Yrkesetiske retningslinjer. Oslo: NSF. Tilgjengelig fra:

https://www.nsf.no/sykepleiefaget/yrkesetiskeretningslinjer (nedlastet 27.08.2021).

6. Norsk Sykepleierforbund (NSF).

Sykepleierpodden \#22. Om å gjøre feil på jobben - når en feil blir forskjellen på liv og død. Oslo: NSF; 02.03.2021. Tilgjengelig fra: https://shows.acast.com/sykepleierpodden/episodes/22 -om-a-gjre-feil-pa-jobben-nar-en-feil-blir-forskjellenpa- (nedlastet 27.08.2021).

7. Oksvold R. Legen hadde ansvaret for at barnet deres døde - ett år senere tok Birgit (29) og Olaf (31) et helt spesielt valg. TV2. 15.10.2017. Tilgjengelig fra: https://www.tv2.no/a/9404651/ (nedlastet 27.08.2021).

8. Brinchmann BS. Etikk i sykepleien. Oslo: Gyldendal Akademisk; 2021. 